\title{
An Analysis of Research Contributions Reflected in Pearl: A Journal of Library and Information Science
}

\author{
N. Padmavathi ${ }^{1 *}$ \\ M. Veerabasavaiah ${ }^{2}$
}

\begin{abstract}
The present study investigates research trends in different disciplines of library of information of science field. The analysis indicates that 300 articles are published during 2007-2014. This study analyses the volume-wise distribution of research contributions, authorship pattern, author affiliation and country-wise distribution of research contributions.
\end{abstract}

Keywords: Research Contributions, Bibliometric Studies, Scientometric Studies, Pearl Journal, Library, Content Analysis, Authorship productivity.

\section{กิ}

LNTRODUCTION

Eearl: A Journal of Library and Information Science 啰 a national periodical completely dedicated to the field of library and information serving the pirofessional community by publishing research apers on diverse fields of library science duly encouraging the authors-young and old around the globe. It is a quarterly journal published since 2007 .

\section{REVIEW OF RELATED LITERATURE} Germa (1995) analysed the 87 research contributions of four volumes of ILA Bulletin and studied the average number of contributions in each volume of this journal. He also studied the authorship pattern, state-wise and institutionwise distribution of research contribution. In addition, he analysed 701 citations that appeared in four volumes of this journal and also presented a list of 23 cited journals and so on.

Razvi and Khan (1996) find out 108 research contributions in five volumes of Herald of Library Science, which is a well-known and a leading journal in the field of library and information science. They present information about contribution in each volume and analyse the authorship pattern, state-wise distribution and affiliation of authors with respect to the institution they serve. Further the contribution of articles to different fields of library and information science is identified.

Bansal et al. (2005) studied content analysis of DESIDOC Bulletin of Information Technology during the period from 2000 to 2004. It is found that recent developments in information technology, as applicable to Library and Information Centers, to help the librarians, documentation and information professionals, students and others interested in the field.

The paper of Tigga et al. (2005) is the outcome of the content analysis of 33 issues of DESIDOC Bulletin of Information Technology (DBIT) published during January 1997 to July 2002. DBIT gives more emphasis on IT-related areas. DBIT is a peer-reviewed journal and publishes thematic issues on different areas of IT, library management and information marketing and the contents of journal are analysed in this study. DBIT is a useful tool for library professionals, information managers, information scientists, and information specialists, computer personnel's and researchers with a vision for development in IT.

${ }^{1}$ Research Scholar, ${ }^{2}$ Professor, Department of Library and Information Science, Bangalore University, Bangalore-560056, Karnataka, India $\left({ }^{*}\right.$ Corresponding author) email id: *padma.hpm@gmail.com; ${ }^{2}$ vrbasavaiah@gmail.com 
An Analysis of Research Contributions Reflected in Pearl: A Journal of Library and Information Science

\section{OBJECTIVES OF THE STUDY}

The present study is an attempt to investigate mainly on the following objectives:

i. To find out the volume-wise distribution of research contributions in each volume

ii. To identify the average number of research contributions in each volume of the source journal

iii. To know the distribution of contributions in various subject disciplines

iv. To find out the authorship productivity of the research contributions

v. To identify the author affiliation of research contributions and

wi. To identify the country-wise distribution of พิ research contributions

\section{SCOPE OF THE STUDY}

Ehe present study is focused on the analysis of ine research contributions from the source journal Eearl: A Journal of Library and Information Science and covers 30 issues from volume 1 to 8 during z007-2014. The research contributions were ånalysed according to the objectives of the present sĭn

\section{部IETHODOLOGY}

A total of 8 volumes were selected for the present study. The data collected on content page of research articles, authors name and their affiliation, country-wise distributions of research publications were analysed.

\section{ANALYSIS OF DATA}

Table 1 presents the volume-wise distribution of research articles in eight volumes. Each volume contains four issues and last volume with three issues. A total of 300 research articles are identified. The highest numbers of articles are found in the year 2009 in volume 3 with 47 $(15.67 \%)$ research articles, followed by 2010 with $45(15 \%)$ research articles in volume 4 and 2008 with $44(14.67 \%)$ articles in volume 2.
Table 1: Volume-wise distribution of research contributions

\begin{tabular}{|c|c|c|c|c|}
\hline Year & $\begin{array}{c}\text { Volume } \\
\text { No. }\end{array}$ & $\begin{array}{c}\text { No. of } \\
\text { issues }\end{array}$ & $\begin{array}{c}\text { No. of } \\
\text { articles }\end{array}$ & Percentage \\
\hline 2007 & 1 & 4 & 29 & 9.67 \\
\hline 2008 & 2 & 4 & 44 & 14.67 \\
\hline 2009 & 3 & 4 & 47 & 15.67 \\
\hline 2010 & 4 & 4 & 45 & 15.00 \\
\hline 2011 & 5 & 4 & 43 & 14.33 \\
\hline 2012 & 6 & 4 & 31 & 10.33 \\
\hline 2013 & 7 & 4 & 34 & 11.33 \\
\hline 2014 & 8 & 3 (up to Sept.) & 27 & 9.00 \\
\hline Total & & $\mathbf{3 1}$ & $\mathbf{3 0 0}$ & $\mathbf{1 0 0}$ \\
\hline
\end{tabular}

Table 2: Average number of research contributions in each volume

\begin{tabular}{|c|c|c|}
\hline No. of volumes & Total No. of articles & Average \\
\hline 8 & 300 & 37.5 \\
\hline
\end{tabular}

From Table 2, it is identified that the research contributions in 31 issues of eight volumes of the source journal is 300 , and the average number of research contributions per volume is 37.5 .

Table 3: Subject-wise contributions of research articles

\begin{tabular}{|l|c|c|}
\hline LIS core subject & $\begin{array}{c}\text { No. of } \\
\text { research } \\
\text { contributions }\end{array}$ & $\begin{array}{c}\text { Perce- } \\
\text { ntage }\end{array}$ \\
\hline $\begin{array}{l}\text { ICT (information and communication } \\
\text { technology, digital library, knowledge } \\
\text { management, E-resource) }\end{array}$ & 160 & 53.33 \\
\hline User study & 47 & 15.67 \\
\hline $\begin{array}{l}\text { Bibliometrics, citation analysis sciento- } \\
\text { metrics and webometrics }\end{array}$ & 41 & 13.67 \\
\hline Foundations of LIS & 27 & 9 \\
\hline Library management & 14 & 4.67 \\
\hline $\begin{array}{l}\text { Marketing of information services and } \\
\text { products }\end{array}$ & 5 & 1.67 \\
\hline Research methodology & 4 & 1.33 \\
\hline Information literacy & 2 & 0.66 \\
\hline Total & $\mathbf{3 0 0}$ & $\mathbf{1 0 0}$ \\
\hline
\end{tabular}

Table 3 presents the distribution of research contributions in LIS core subject. Out of 300 research contributions, the highest number of research articles is $160(53.33 \%)$ on ICT, followed by user study with $47(15.67 \%)$, bibliometrics and its related area with $41(13.67 \%)$ and information literacy with $2(0.66 \%)$. 
Table 4: Authorship productivity of research contributions

\begin{tabular}{|l|c|c|}
\hline No. of authors & $\begin{array}{c}\text { No. of research } \\
\text { contribution }\end{array}$ & Percentage \\
\hline Single author & 121 & 40.33 \\
\hline Multiple authors & 179 & 59.67 \\
\hline Total & $\mathbf{3 0 0}$ & $\mathbf{1 0 0}$ \\
\hline
\end{tabular}

Table 4 examines that the authorship productivity of research articles represents the multiple authors research contribution with $179(59.67 \%)$, followed by single author contribution with 121 (40.33\%).

Table 5: Author affiliation of research contributions

\begin{tabular}{|l|c|c|}
\hline Author affiliation & $\begin{array}{c}\text { No. of research } \\
\text { contributions }\end{array}$ & Percentage \\
\hline Non-teaching LIS professionals & 207 & 69 \\
\hline Teaching LIS professionals & 90 & 30 \\
\hline Znncomplete (no address/affiliation) & 3 & 1 \\
\hline Trotal & $\mathbf{3 0 0}$ & $\mathbf{1 0 0}$ \\
\hline
\end{tabular}

Eable 5 shows the author affiliation of research c్ontributions. There are $207(69 \%)$ research entributions from non-teaching LIS professionals, . teching LIS professionals. There are $3(1 \%)$ esearch contributions which have incomplete infformation from author affiliations.

Table 6: Country-wise distribution of research contributions

\begin{tabular}{|l|c|c|}
\hline Name of the countries & $\begin{array}{c}\text { No. of research } \\
\text { contributions }\end{array}$ & Percentage \\
\hline India & 282 & 94.00 \\
\hline Nigeria & 9 & 3.00 \\
\hline UAE (United Arab Emirates) & 2 & 0.68 \\
\hline Bangladesh & 1 & 0.33 \\
\hline Belgium & 1 & 0.33 \\
\hline Iran & 1 & 0.33 \\
\hline Saudi Arabia & 1 & 0.33 \\
\hline Incomplete & 3 & 1.00 \\
\hline Total & $\mathbf{3 0 0}$ & $\mathbf{1 0 0}$ \\
\hline
\end{tabular}

Table 6 shows the country-wise distribution of research contributions in volume 8 of the source journal. Out of 300 research article contributions the highest $282(94 \%)$ has been contributed by Indian authors, followed by Nigeria with 9 (3\%) contributions. There are $3(1 \%)$ incomplete contributions, UAE with 2 (0.68\%), Bangladesh, Belgium, Iran and Saudi Arabia each with 1 $(0.33 \%)$ research contributions.

\section{FINDINGS AND CONCLUSION}

The following findings and conclusions can be drawn from the present study:

1. It is observed in Table 1 that the highest number of articles is $47(15.67 \%)$ in 2009 followed by $45(15.46 \%)$ articles in 2010.

2. It is observed in Table 2 that the average number of research contributions per volume is $37.5 \%$.

3. It is clear from Table 4 that majority 179 $(59.67 \%)$ of the contributions are from multiple authors, followed by $121 \quad(40.33 \%)$ contributions from single author.

4. Table 5 shows the author affiliation of research contributions in different institutions. There are $207(69 \%)$ contributions from nonteaching LIS professionals, followed by 90 $(30 \%)$ contributions from teaching LIS professionals.

5. Most of the articles are published on information technology with 160 (53.33\%), followed by user study with 47 (15.67\%). bibliometrics and its related areas with 41 $(13.67 \%)$ and lastly information literacy with $2(0.66 \%)$.

6. Table 6 shows the country-wise distribution. India contributed $282(94 \%)$ out of 300 contributions, followed by Nigeria with 9 (3\%) contributions and the remaining countries with small number of research contributions.

\section{REFERENCES}

Anitha MK, 2001. Analysis of contributions of information studies. Bangalore: Bangalore University.

Bansal A, Kumari V, Kumar A and Singh M, 2005. DESIDOC Bulletin of Information Technology: Success story with content coverage during 2000-2004. DESIDOC Bulletin of Information Technology, Vol. 25, No. 4, pp. 19-30.

Berelson B, 1952. Content analysis in communications research. Glencoe: The Free Press.

Holsti Ole R, 1969. Content analysis for the social sciences and humanities. Reading, MA: Addison-Wisely. 
An Analysis of Research Contributions Reflected in Pearl: A Journal of Library and Information Science

Krippendorff K, 2004. Content analysis: an introduction to its methodology. $2^{\text {nd }}$ ed. New Delhi: Sage Publication, pp. 18.

Mohamed HK and Nellikka S, 2010. Content analysis of online English newspapers in India. DESIDOC Bulletin of Information Technology, Vol. 30, No. 4, pp. 17-24.

Razvi R and Khan AA, 1996. Analysis of contributions of Herald of Library Science. Herald of Library Science, Vol. 35, No. 3-4, pp. 189-194.

Tankar AS, Dharmapurikar RG and Mete MV, 2002. Content analysis of economic and political weekly. ILA Bulletin, Vol. 38, No. 2, pp. 52-56.
Tigga UP, Lihitkar SR and Rajyalakshmi D, 2005. Content analysis of DESIDOC Bulletin of Information Technology (1997-2002). DESIDOC Bulletin of Information Technology, Vol. 25, No. 4, pp. 5-18.

Verma N, 2004. Analysis of contributions of IASLIC Bulletin. IASLIC Bulletin, Vol. 49, No. 2, pp. 93-103.

Verma N, 1995. Analysis of contributions of ILA Bulletin. ILA Bulletin, Vol. 30, No. 3-4, pp. 73-83.

Verma N, 2001. Analysis of contributions of Library Herald. Library Herald, Vol. 39, No. 1-2, pp. 32-49. 